\title{
Analysis of the Relationship between Density and Mechanical Strength of Lightened Gypsums: Proposal for a Coefficient of Lightening
}

\author{
Jaime Santa Cruz Astorqui, Mercedes del Río Merino, \\ Paola Villoria Sáez, and César Porras-Amores \\ Universidad Politécnica de Madrid, Escuela Técnica Superior de Edificación, TEMA Research Group, Madrid, Spain \\ Correspondence should be addressed to Paola Villoria Sáez; paola.villoria@upm.es
}

Received 4 May 2017; Accepted 5 September 2017; Published 10 October 2017

Academic Editor: Jose M. Monzo

Copyright (c) 2017 Jaime Santa Cruz Astorqui et al. This is an open access article distributed under the Creative Commons Attribution License, which permits unrestricted use, distribution, and reproduction in any medium, provided the original work is properly cited.

\begin{abstract}
This article develops a relationship between the reduction of density in lightened gypsum and the addition of expanded and/or extruded polystyrene waste from the construction sector and their mechanical behavior. The equations determined in this study allow us to know the flexural and compressive strengths of a lightened gypsum/plaster compound once its density is known. The results show that there is an exponential relationship between the density of the compound and its strength. The methodology followed included a compilation of the results obtained in previous research works on lightweight gypsums, analyzing the relationship between density and mechanical strength and comparing them with the equations developed in this research. The results obtained by previous researchers have a good adjustment with the proposed models, and only perlite compounds present greater deviations in the compressive strength analysis. Also, a dimensionless lightening coefficient is defined which can help to determine the best application for a lightweight gypsum compound, comparing it with an ideal lightweight gypsum.
\end{abstract}

\section{Introduction}

The lightweight materials are those that originally have normal densities and by some procedure its density can be reduced. This procedure consists of taking part of its volume with a much lower density material (air or even solid cells such as lightweight aggregates), making it a cellular material. Although there are various methods to lighten building materials, in the case of conglomerate materials, the incorporation of lightweight aggregates as filler in the fresh compound is usually the most common and simplest technique to lighten building materials [1].

An aggregate is considered light when the actual grain density is less than $1200 \mathrm{~kg} / \mathrm{m}^{3}$ [2]. The addition of lightweight aggregates in the conglomerate has as advantages, besides reducing the density, increasing material performance, improving the granulometry making more workable the mass, and improving their thermal and acoustic characteristics.
The first light aggregates that were incorporated into the materials were the volcanic aridity; an example of this is the construction of the dome of the Pantheon in Rome in the second century $\mathrm{BC}$, with a mortar lightened with pumice. But it was not until 1917 when its use in the construction of buildings was generalized, as load in mortars and concrete, when lightweight aggregates were manufactured by an industrial process of expanding clay [3].

In the case of gypsum, various methods have been studied to lighten it [4]. Standard UNE-EN-13279-1 defines the compounds formed by a mixture of calcium sulphate in its different stages of dehydration (anhydrite, hemihydrate, or dihydrate) and purity (traditionally known as crude gypsum, fine gypsum, or plaster) as lightened gypsums, with a certain content of lime (calcium hydroxide), which incorporates lightweight inorganic or organic lightweight aggregates [5]. Therefore, only the gypsums incorporating such loads would be included in the group of lightweight gypsums. 
These gypsums usually have better thermal properties, enabling energy savings in buildings and a decrease in emissions of greenhouse gases such as $\mathrm{CO}_{2}$. In addition, reducing the density of the material enables the manufacture of lighter construction elements, facilitating its placing and transport.

1.1. Review on Lightened Gypsums. After World War II, the changes produced in the characteristics of gypsum begin to be scientifically studied, by using additives and admixtures [6]. In the case of lightened gypsums expanded perlite and exfoliated vermiculite additions are studied $[7,8]$.

(i) Perlite is a mineral insulation, produced from volcanic rocks, with a density close to $1100 \mathrm{~kg} / \mathrm{m}^{3}$. For its use in construction it is necessary to subject it to a physical expansion process in which the volume increases 20 times, creating microcells in its interior and reducing its density to values between 30 and $150 \mathrm{~kg} / \mathrm{m}^{3}$.

(ii) Vermiculite belongs to the family of mica and is basically made of aluminum, iron, and magnesium silicates. Like perlite, after a physical process it is exfoliated and its volume increases 16 times, reducing its density values between 60 and $160 \mathrm{~kg} / \mathrm{m}^{3}$.

Although these lightweight aggregates are a good alternative to lighten gypsum compounds-they have densities 15 times lower than the sand and 8 times less than the expanded clay or volcanic rocks-their use generates a great environmental impact, consuming large amount of energy during their manufacture, as high temperatures are needed $\left(800-1100^{\circ} \mathrm{C}\right)$ [9]. Therefore, researchers have been looking for ways to replace them with other light loads in order to obtain lightened gypsums that meet the requirements of current regulations.

After a bibliographic and document search on the subject, several studies have been found incorporating expanded clay additions in gypsum compounds-getting to reduce the gypsum density by $20 \%$, in the best cases [10]-expanded polystyrene granules [11] or cork [12], reducing the density by $50 \%$. Also, other researchers are working with other light loads from building construction and demolition waste (CDW) as cellular glass [13] or expanded and extruded polystyrene $[14,15]$.

However, in all the works above, the obtained lightened gypsums reached significant reductions in mechanical strength, confirming that the strength of the gypsum depends mainly on its porosity and therefore its density. In this sense, several studies have been conducted trying to improve physical and mechanical behavior of lightened gypsums by incorporating fibers $[16,17]$. Among these studies the study by Gencel et al. (2014) can be highlighted, as it incorporates polypropylene fibers to lightened gypsums with vermiculite [18].

Despite the numerous works found on lightened gypsums, all of them are based on the chemical and mechanical characterization of the compounds obtained. However, no works have been found analyzing the relationship between density and strength of the lightened gypsums.

Therefore, in this article the relationship between the density reduction of lightened gypsums and lightweight loads from CDW and their mechanical behavior is analyzed.

In addition, it is analyzed whether this relationship is similar to the one obtained for other lightened gypsums with other fillers which are often used in the manufacture of gypsum elements. Also lightening coefficients are defined, which allow determining the best application of a lightened gypsum, relating the strength and density of the compound to an ideal lightened gypsum.

\section{Method}

A compilation of results obtained in previous investigations (density and mechanical strength) was performed considering lightened gypsums with different light loads (with w/g ratio $=0.8)$. These works were completed with the results of a pilot scheme with lightened gypsums with mixtures of waste of expanded (EPS) and extruded (XPS) polystyrene in different percentages of addition on the weight of the gypsum $[19,20]$ (Table 1).

Each compound is defined by an abbreviated formula of all components in which first the type of binder is defined: coarse gypsum B1 (YG) or plaster A (E), followed by the water-binder ratio of the compound. The next element refers to the percentage of waste with respect to the weight of the gypsum/plaster, followed by the type of light load used in the mixture. In those compounds where more than one type of waste is included, the information is inserted after, following the previous nomenclature.

Subsequently, the relationship between the density and the mechanical strength of all lightened gypsums with mixtures of EPS/XPS was analyzed using Excel program. A trend equation for both compressive and flexural strength of these lightened gypsums - once their density is known-was obtained together with the coefficient of determination $\left(R^{2}\right)$ to know their adjustment. Finally, both mathematical models were validated with the results published in previous research works on lightened gypsums using other procedures.

Finally, with the results of the compounds meeting the minimum specifications required for lightened gypsums (B4) [22] (flexural strength: $\geq 1 \mathrm{MPa}$; compressive strength: $\geq 2 \mathrm{MPa}$; density $\leq 1 \mathrm{~g} / \mathrm{cm}^{3}$ ), lightening coefficients for the mechanical properties of the gypsums were calculated, using (1) defined by del Rio Merino [23].

$$
\begin{aligned}
\operatorname{Kflex}_{n} & =\frac{D_{n}}{\text { Flexural Strength }_{n}}, \\
\operatorname{Kcomp}_{n} & =\frac{D_{n}}{\text { Compression Strength }_{n}},
\end{aligned}
$$

where $n$ is the analyzed compound, $D_{n}$ is density of compound $n, K$ flex $_{n}$ is the lightening coefficient according to the flexural strength of compound $n$, and $K \operatorname{comp}_{n}$ is the lightening coefficient according to the compressive strength of compound $n$. 
TABLE 1: Results obtained in previous works on lightened gypsums by various methods.

\begin{tabular}{|c|c|c|c|c|}
\hline Procedure used to lighten & Compound & $D\left(\mathrm{~g} / \mathrm{cm}^{3}\right)$ & Flex. s (MPa) & Comp. s (MPa) \\
\hline \multirow{8}{*}{ Adding lightweight aggregates $[4,7,16]$} & $\mathrm{E} 0.8+\operatorname{Ar} 40 \%$ & 0.96 & 2.82 & $:$ \\
\hline & $\mathrm{E} 0.8+\operatorname{Ar} 50 \%$ & 0.93 & 2.93 & $:$ \\
\hline & $\mathrm{E} 0.8+\operatorname{Ar} 60 \%$ & 0.92 & 2.26 & $:$ \\
\hline & E0.8 + EPS 3\% (pearls of EPS) & 0.50 & 1.00 & 1.70 \\
\hline & E0.8 $+10 \%$ perlite & 0.76 & 2.23 & 4.50 \\
\hline & E0.8 $+20 \%$ perlite & 0.78 & 2.25 & 5.40 \\
\hline & E0.8 $+20 \%$ vermiculite & 0.82 & 2.45 & 3.78 \\
\hline & $\mathrm{E} 0.8+20 \%$ VC waste & 0.79 & 2.31 & 3.05 \\
\hline \multirow{2}{*}{ Increasing $\mathrm{w} / \mathrm{g}$ ratio $[4,7,16]$} & E1.0 & 0.82 & 2.20 & 4.53 \\
\hline & E2.0 & 0.48 & 0.58 & 0.76 \\
\hline \multirow{6}{*}{ Adding lightweight aggregate waste + increasing $\mathrm{w} / \mathrm{g}$ ratio [21] } & YG0.9 + 4\% EPS waste & 0.42 & 0.55 & 0.41 \\
\hline & YG1.0 + 4\% EPS waste & 0.41 & 0.45 & 0.43 \\
\hline & YG1.1 + 4\% EPS waste & 0.52 & 0.58 & 0.71 \\
\hline & YG1.5 + 5\% EPS waste & 0.32 & : & 0.31 \\
\hline & YG1.6 + 5\% EPS waste & 0.31 & : & 0.26 \\
\hline & YG1.8 + 5\% EPS waste & 0.29 & : & 0.26 \\
\hline \multirow{3}{*}{ Adding aerating and foaming $[4,7,16]$} & $\mathrm{E}+0.5 \%$ aerating $\mathrm{SKG}$ & 0.95 & : & : \\
\hline & $\mathrm{E}+3 \%$ foaming base resin & 0.88 & 2.70 & 2.75 \\
\hline & $\mathrm{E}+2 \%$ protein based foaming & 0.59 & $:$ & $:$ \\
\hline \multirow{31}{*}{ Adding EPS+XPS waste $[19,20]$} & E0.8 & 0.99 & 3.98 & 8.34 \\
\hline & $\mathrm{E} 0.8+1 \% \mathrm{EPS}$ & 0.82 & 2.64 & 4.04 \\
\hline & $\mathrm{E} 0.8+1 \%$ XPS & 0.94 & 2.73 & 4.50 \\
\hline & $\mathrm{E} 0.8+2 \% \mathrm{EPS}$ & 0.71 & 2.05 & 2.74 \\
\hline & $\mathrm{E} 0.8+2 \% \mathrm{XPS}$ & 0.88 & 2.88 & 5.59 \\
\hline & $\mathrm{E} 0.8+1 \% \mathrm{EPS} / \mathrm{XPS}$ & 0.74 & 2.28 & 3.09 \\
\hline & $\mathrm{E} 0.8+1.5 \% \mathrm{EPS}+0.5 \% \mathrm{XPS}$ & 0.67 & 2.01 & 2.89 \\
\hline & $\mathrm{E} 0.8+0.5 \% \mathrm{EPS}+1.5 \% \mathrm{XPS}$ & 0.78 & 2.64 & 4.39 \\
\hline & $\mathrm{E} 0.8+2.0 \% \mathrm{EPS}+0.5 \% \mathrm{XPS}$ & 0.76 & 2.35 & 3.73 \\
\hline & $\mathrm{E} 0.8+1.0 \% \mathrm{EPS}+1.5 \% \mathrm{XPS}$ & 0.77 & 2.32 & 4.57 \\
\hline & E0.8 + 1.0\% EPS + 2.0\% XPS & 0.84 & 2.81 & 5.45 \\
\hline & E0.8 + 2.0\% EPS + 1.0\% XPS & 0.74 & 2.36 & 3.81 \\
\hline & $\mathrm{E} 0.8+2.0 \% \mathrm{EPS}+2.0 \% \mathrm{XPS}$ & 0.71 & 2.08 & 3.56 \\
\hline & YG0.8 & 0.99 & 3.26 & 5.79 \\
\hline & YG0.8 + 1\% EPS & 0.82 & 2.25 & 2.96 \\
\hline & YG0.8 + 1\% XPS & 0.97 & 2.00 & 3.04 \\
\hline & YG0.8 + 2\% EPS & 0.64 & 1.24 & 1.46 \\
\hline & YG0.8 + 2\% XPS & 0.90 & 2.05 & 3.01 \\
\hline & $\mathrm{E} 0.8+1 \% \mathrm{EPS} / \mathrm{XPS}$ & 0.73 & 1.85 & 2.44 \\
\hline & YG0.8 + 1.5\% EPS + 0.5\% XPS & 0.67 & 1.47 & 1.94 \\
\hline & YG0.8 + 0.5\% EPS + 1.5\% XPS & 0.90 & 2.27 & 3.39 \\
\hline & YG0.8 + 2.0\% EPS + 0.5\% XPS & 0.71 & 1.59 & 2.66 \\
\hline & YG0.8 + 1.0\% EPS + 1.5\% XPS & 0.81 & 1.93 & 2.97 \\
\hline & YG0.8 + 1.0\% EPS + 2.0\% XPS & 0.76 & 1.59 & 2.30 \\
\hline & YG0.8 + 2.0\% EPS + 1.0\% XPS & 0.58 & 0.99 & 1.05 \\
\hline & YG0.8 + 2.0\% EPS + 2.0\% XPS & 0.60 & 0.95 & 1.07 \\
\hline & YG0.8 + 3\% EPS & 0.56 & 0.95 & 1.14 \\
\hline & YG0.8 + 3.5\% EPS & 0.60 & 1.23 & 1.58 \\
\hline & YG0.8 + 4\% EPS & 0.49 & 0.82 & 0.89 \\
\hline & YG0.8 + 4.5\% EPS & 0.50 & 0.94 & 0.87 \\
\hline & YG0.8 + 5\% EPS & 0.48 & 0.89 & 0.78 \\
\hline
\end{tabular}


These coefficients provide a reference value to determine whether a material of lightened plaster, from the point of view of strength, has a weight/strength ratio suitable for the future application it will have.

Moreover, an ideal lightening coefficient is proposed. This coefficient is determined using the values of the gypsum reference (without additions). In any case, these coefficients can be generalized and used to analyze other properties of the gypsum wishing to be studied for specific applications of the material, such as surface hardness, thermal conductivity, and water absorption:

$$
\begin{aligned}
& K i_{\text {Property analyzed }} \\
& \quad=\frac{0.5 \times D_{\text {ref }}}{\text { Value of the property analyzed }} \text { Regulation }
\end{aligned}
$$

where $D_{\text {ref }}$ is density of the reference compound, $K i_{\text {property analyzed }}$ is the ideal coefficient according to the property analyzed, and Regulation refers to minimum values prescribed in the regulations.

In the case discussed in this article (density and strength) the ideal gypsum would be that one which has half of the density of the gypsum of reference and at least the minimum mechanical properties set by the regulations:

$$
\begin{aligned}
& K i_{\text {flex }}=\frac{0.5 \times D_{\text {ref }}}{\text { Flexural Strength }} \text { Regulation }_{\text {ind }}=\frac{0.5 \times D_{\text {ref }}}{1 \mathrm{MPa}}, \\
& K i_{\text {comp }}=\frac{0.5 \times D_{\text {ref }}}{\text { Compression Strength } \text { Regulation }} \\
& =\frac{0.5 \times D_{\text {ref }}}{2 \mathrm{MPa}},
\end{aligned}
$$

where $K i_{\text {flex }}$ and $K i_{\text {comp }}$ are ideal lightening coefficients as flexural and compression strength, respectively, $D_{\text {ref }}$ is density of the reference compound, and Regulation refers to values of standard UNE-EN 13279-1 for lightened gypsums (flexural strength $=1 \mathrm{MPa}$; compressive strength $=2 \mathrm{MPa}$ ).

Finally, the lightening coefficients obtained were compared with the coefficient of the ideal lightened gypsum $(K i)$.

\section{Results and Discussion}

3.1. Model to Estimate the Mechanical Strength of a Lightened Compound of Gypsum Known Its Density. With all compounds made with EPS and XPS the relationship between the density of the compounds and their mechanical resistance is analyzed (Figures 1 and 2). In all cases, it is observed that the results achieved with plaster type A present strengths slightly above the compounds of coarse gypsum B1. Moreover, in both cases, the compounds that best fit the model are made with EPS or mixtures of EPS/XPS. For compressive strength, the compounds of plaster with XPS have higher dispersions than the results of the compounds only with EPS.

Finally, it is observed that there is a potential relationship between the density of the compound and its mechanical resistance to both compression and flexion, with an adjustment around $R^{2}=0.78$. Therefore, the compressive and

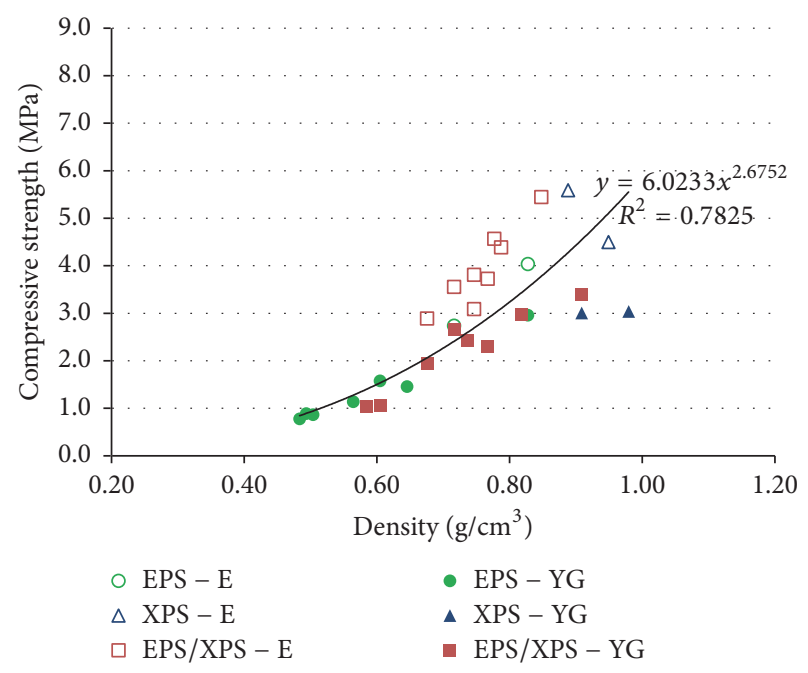

FIGURE 1: Relationship between compressive strength and the density of the compound.

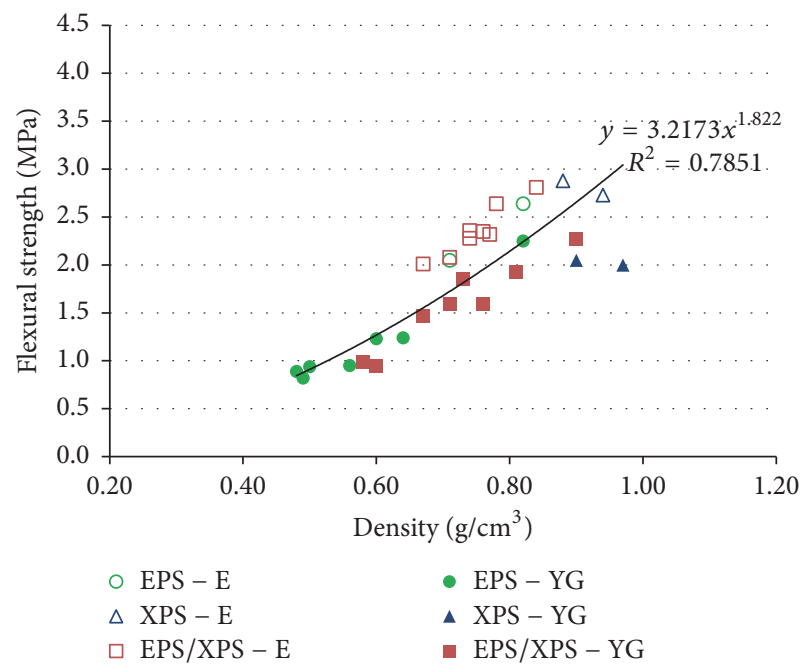

FIGURE 2: Relationship between flexural strength and the density of the compound.

flexural strength compound lightened with EPS and XPS can be estimated once its density is known, with the following expressions:

$$
\begin{aligned}
\text { Compressive strength } & =6,0233 \times d^{2,6725}, \\
\text { Flexural strength } & =3,2173 \times d^{1,822},
\end{aligned}
$$

where one has the following:

(i) Compressive and flexural strength in MPa.

(ii) Density in $\mathrm{g} / \mathrm{cm}^{3}$.

Next, Figures 3 and 4 compare the model with the results obtained in previous research works using other procedures to lighten gypsum compounds (Table 1).

It shows that there is a better fit of the data to model of flexural strength compared with compression. In all cases, 


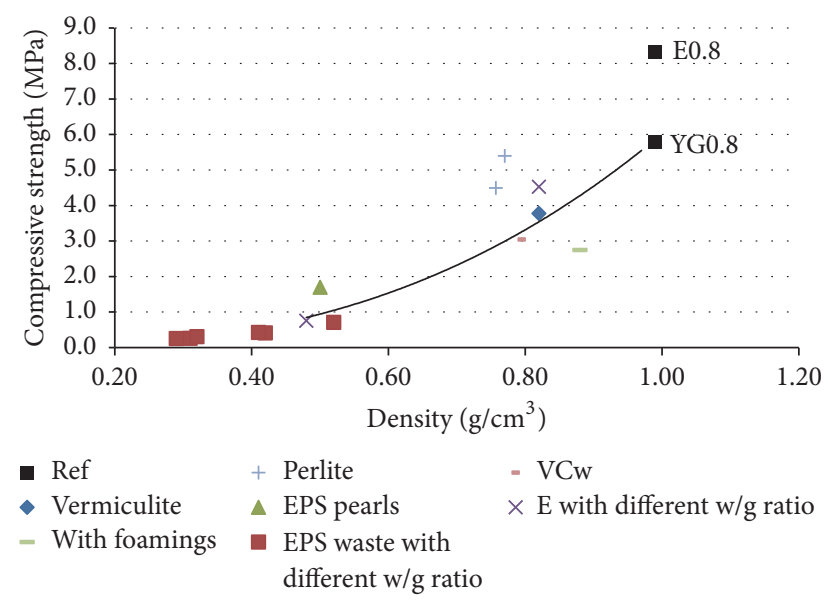

FIgURE 3: Comparison of proposed model with the results obtained by other authors. Compressive strength.

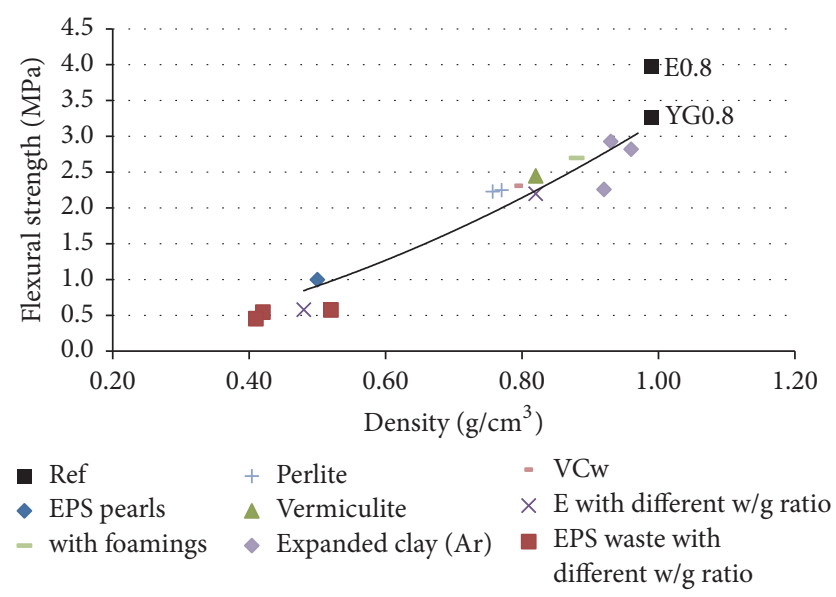

FIGURE 4: Comparison of proposed model with the results obtained by other authors. Flexural strength.

the results of other researchers have a good adjustment with the proposed model; only the compounds of perlite have a greater deviation in the model of the compressive strength. This deviation may be due to the nature and characteristics of the type of lightweight load added (density, strength, and adhesion to the gypsum/plaster). In particular, the perlite has greater mechanical resistance, due to its mineral origin. This also happens with the vermiculite. These factors definitely influence the compressive strength of the compound.

3.2. Lightening Coefficients. Table 2 shows the lightening coefficients obtained with the weights and mechanical strength of the compounds.

These coefficients allow for the comparison of different types of lightened gypsums and consider their possible application as a material for construction elements. In this case, as the selected gypsums can be used to manufacture construction elements for inner partitions, a compound with

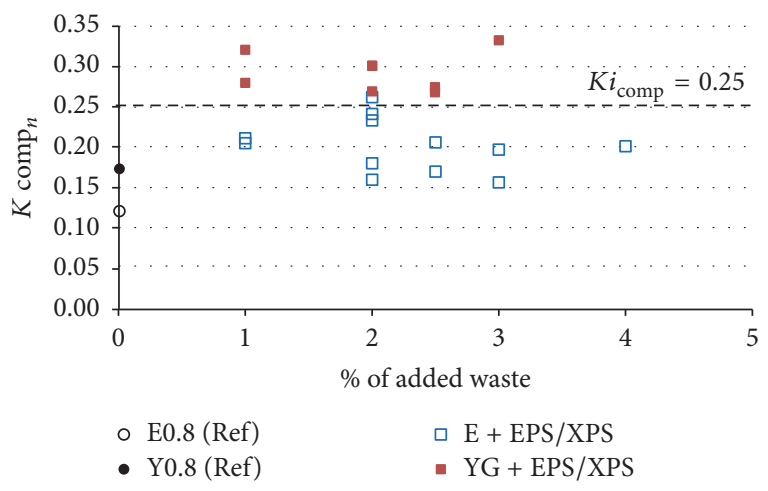

FIGURE 5: Lightening coefficients of the compounds tested according to compressive strength.

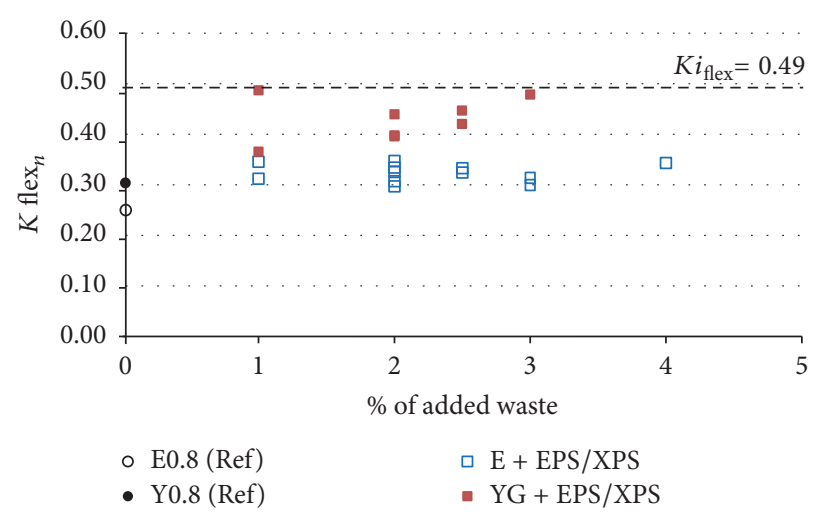

FIGURE 6: Lightening coefficients of the compounds tested according to flexural strength.

good overall mechanical behavior will be selected, that is, with similar coefficient to the reference gypsums or lower.

Lower values are not achieved, but it is observed that some of the lightened gypsums obtain good coefficients only for flexural or compression strength (e.g., plasters lightened with perlite), and instead the gypsums lightened with polystyrene waste $(\mathrm{E} 0.8+0.5 \% \mathrm{EPS}+1.5 \%$ XPS and E0.8 $+2.0 \%$ EPS $+1.0 \%$ XPS) obtained good coefficients in both flexural and compression.

In Figures 5 and 6 the lightening coefficients for each specimen are shown-calculated with (1) - as for the percentage of waste added. Moreover, the value of the ideal lightening coefficient has been marked with a dashed line $\left(K i_{\text {flex }} ; K i_{\text {comp }}\right)$, calculated with (3).

The relationship between the two coefficients is shown in Figure 7, considering the waste added: only EPS, XPS alone, or mixture thereof.

It is observed that, generally, all compounds have good performance as they present lower lightening coefficients than the one of the ideal compound $(K i)$. In particular, the compounds of plaster type A with EPS and XPS are those which offer results very similar to the ones obtained with the gypsum reference samples (without any added waste).

This coefficient can be generalized in the case of having to analyze other characteristics of the gypsum. For example, 
TABLE 2: Lightening coefficients of selected lightened gypsums.

\begin{tabular}{|c|c|c|}
\hline Compounds complying with lightweight gypsum regulation & $K \mathrm{flex}_{n}$ & $K \operatorname{comp}_{n}$ \\
\hline E0.8 & 0.25 & 0.12 \\
\hline Y0.8 & 0.30 & 0.17 \\
\hline E0.8+1\% EPS & 0.31 & 0.20 \\
\hline $\mathrm{E} 0.8+1 \% \mathrm{XPS}$ & 0.34 & 0.21 \\
\hline $\mathrm{E} 0.8+2 \% \mathrm{EPS}$ & 0.35 & 0.26 \\
\hline $\mathrm{E} 0.8+2 \% \mathrm{XPS}$ & 0.31 & 0.16 \\
\hline E0.8 + 1\% EPS/XPS & 0.32 & 0.24 \\
\hline $\mathrm{E} 0.8+1.5 \% \mathrm{EPS}+0.5 \% \mathrm{XPS}$ & 0.33 & 0.23 \\
\hline $\mathrm{E} 0.8+0.5 \% \mathrm{EPS}+1.5 \% \mathrm{XPS}$ & 0.30 & 0.18 \\
\hline $\mathrm{E} 0.8+2.0 \% \mathrm{EPS}+0.5 \% \mathrm{XPS}$ & 0.32 & 0.20 \\
\hline $\mathrm{E} 0.8+1.0 \% \mathrm{EPS}+1.5 \% \mathrm{XPS}$ & 0.33 & 0.17 \\
\hline $\mathrm{E} 0.8+1.0 \% \mathrm{EPS}+2.0 \% \mathrm{XPS}$ & 0.30 & 0.15 \\
\hline $\mathrm{E} 0.8+2.0 \% \mathrm{EPS}+1.0 \% \mathrm{XPS}$ & 0.31 & 0.19 \\
\hline $\mathrm{E} 0.8+2.0 \% \mathrm{EPS}+2.0 \% \mathrm{XPS}$ & 0.34 & 0.20 \\
\hline Y0.8+1\% EPS & 0.36 & 0.28 \\
\hline Y0.8 + 1\% XPS & 0.49 & 0.32 \\
\hline $\mathrm{Y} 0.8+2 \% \mathrm{XPS}$ & 0.44 & 0.30 \\
\hline E0.8 + 1\% EPS/XPS & 0.39 & 0.30 \\
\hline Y0.8 $+0.5 \%$ EPS $+1.5 \%$ XPS & 0.40 & 0.27 \\
\hline $\mathrm{Y} 0.8+2.0 \% \mathrm{EPS}+0.5 \% \mathrm{XPS}$ & 0.45 & 0.27 \\
\hline $\mathrm{Y} 0.8+1.0 \% \mathrm{EPS}+1.5 \% \mathrm{XPS}$ & 0.42 & 0.27 \\
\hline Y0.8 + 1.0\% EPS + 2.0\% XPS & 0.48 & 0.33 \\
\hline
\end{tabular}

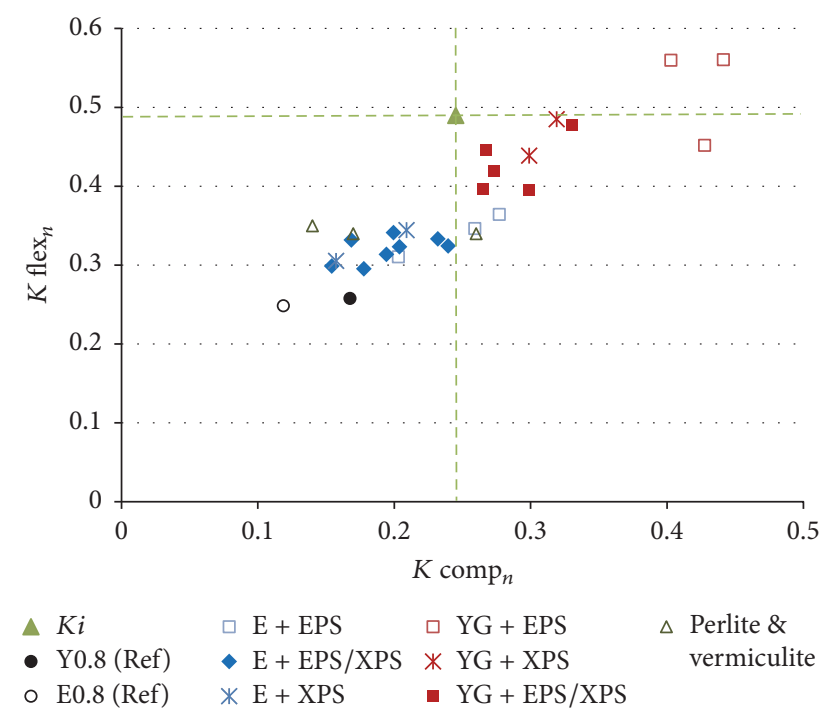

Figure 7: Relationship between the flexural and compression strength coefficients according to the type of waste added.

if we had to select a plaster coating, then the characteristics to analyze would be the surface hardness and adherence and we would calculate the ideal lightening coefficient with the values of the reference gypsum.

\section{Conclusions}

Two mathematical equations have been determined that allow knowing the flexural and compressive strength of a gypsum/plaster compound lightened with EPS and XPS once its density is known (see (4)).

This model can be used for any lightened gypsum, as it has been validated with the results of previous research on lightened gypsums with other procedures. In short, the proposed model allows preliminary studies regarding the mechanical strength of lightened gypsum compounds, knowing only their density.

An ideal lightening coefficient is defined that allows selecting lightened gypsum with good performance for a particular application.

In that sense and considering the case study, plaster type A lightened with EPS and XPS waste, compounds with further addition of XPS waste, are those that approach the most to the lightening coefficient of an ideal lightened gypsum with a good mechanical behavior.

\section{Conflicts of Interest}

The authors declare that there are no conflicts of interest regarding the publication of this paper. 


\section{Acknowledgments}

This research was supported by the Ministry of Economy and Competitiveness of the Spanish Government (Project Reference no. BIA2013-43061-R).

\section{References}

[1] M. del Río Merino and P. Comino, "Análisis de los refuerzos mixtos de fibras de vidrio E y fibras AR en la escayola, como alternativa a los refuerzos monofibras (homogéneos)," Materiales de Construcción, pp. 33-42, 2002.

[2] UNE-EN 13055-1, "Part 1:Lightweight aggregates for concrete, mortar and grout," 2003.

[3] S. J. Hayde, "Method of burning argillaceous material and product resulting therefrom," Patent US1707395 A, 1929.

[4] M. Del Río and F. F. Olivares, "Lightened plaster: alternative solutions to cellular solids addition," Materiales de Construcción, vol. 54, pp. 65-77, 2004.

[5] UNE-EN 13279-1, "Gypsum binders and gypsum plasters. Part 1: Definitions and requirements," S. A. f. S. a. Certification, 2009.

[6] L. de Villanueva Domínguez, "Evolución histórica de la construcción con yeso," Informes de la Construcción, vol. 56, pp. 511, 2004.

[7] M. del Río Merino, J. Domínguez, and F. H. Olivares, "Escayola aligerada con sólidos celulares," Informes de la Construcción, vol. 50, pp. 43-60, 1998.

[8] J. Benedí Oliver, La construcción eficiente energéticamente como necesidad de futuro y su aplicación a un edificio en Valencia, Departament d'Enginyeria Mecànica i Construcció, Universitat Jaume I, Valencia, Spain, 2013.

[9] J. M. Berná Serna, "Evolución de las propiedades mecánicas de los morteros aditivados de yeso con vermiculita," 2013.

[10] M. Serhat Başpinar and E. Kahraman, "Modifications in the properties of gypsum construction element via addition of expanded macroporous silica granules," Construction and Building Materials, vol. 25, no. 8, pp. 3327-3333, 2011.

[11] F. González Madariaga, "Mixtures of waste expanded polystyrene (EPS) with gypsum or gypsum plaster for use in construction," Informes de la Construcción, vol. 60, pp. 35-43, 2008.

[12] F. Hernández-Olivares, M. R. Bollati, M. Del Rio, and B. PargaLanda, "Development of cork-gypsum composites for building applications," Construction and Building Materials, vol. 13, no. 4, pp. 179-186, 1999.

[13] S. R. Piñeiro, M. Del Río Merino, and C. Pérez García, "New Plaster Composite with Mineral Wool Fibres from CDW Recycling," Advances in Materials Science and Engineering, vol. 2015, Article ID 854192, 2015.

[14] A. San-Antonio-González, M. Del Río Merino, C. Viñas Arrebola, and P. Villoria-Sáez, "Lightweight material made with gypsum and extruded polystyrene waste with enhanced thermal behaviour," Construction and Building Materials, vol. 93, article no. 6644, pp. 57-63, 2015.

[15] A. San-Antonio-González, M. D. R. Merino, C. V. Arrebola, and P. Villoria-Sáez, "Lightweight material made with gypsum and eps waste with enhanced mechanical strength," Journal of Materials in Civil Engineering, vol. 28, no. 2, Article ID 04015101, 2016.

[16] A. G. Santos, "PPF-reinforced, ESP-lightened gypsum plaster," Materiales de Construccion, vol. 59, no. 293, pp. 105-124, 2009.
[17] O. Gencel, J. J. Del Coz Diaz, M. Sutcu, F. Koksal, F. P. Álvarez Rabanal, and G. Martínez-Barrera, "A novel lightweight gypsum composite with diatomite and polypropylene fibers," Construction and Building Materials, vol. 113, pp. 732-740, 2016.

[18] O. Gencel, J. J. Del Coz Diaz, M. Sutcu et al., "Properties of gypsum composites containing vermiculite and polypropylene fibers: Numerical and experimental results," Energy and Buildings, vol. 70, pp. 135-144, 2014.

[19] M. Del Río Merino, J. Santa Cruz Astorqui, P. Villoria Sáez, C. Rodríguez Liñán, and M. P. Mercader Moyano, "Valorization of the waste generated in building retrofitting works: waste to resources," in proceedings of the III International Congress of Sustainable Construction and Eco-eficcient solutions, Seville, Spain, 2017.

[20] A. Vilardi, "Mechanical and thermal behaviour of a lightened gypsum plaster with expanded and extruded polystyrene," in Laurea Magistrale in Ingegneria dei Sistemi Edilizi, Dipartimento di Ingegneria Civile, Ambientale, Aerospaziale, dei Materiali (DICAM), University of Palermo, Palermo, Italy, 2017.

[21] J. Santa Cruz Astorqui, M. Del Rio Merino, and P. Villoria Sáez, "Re-design of plaster prefabricated elements," in proceedings of the III International Congress on Construction and Building Research (COINVEDI), Madrid, Spain, 2015.

[22] RP 35.03, "Reglamento particular de la marca AENOR para yesos y escayolas de construcción, sus prefabricados y productos afines. Yesos de construcción aligerados (B4)," 2009.

[23] M. del Rio Merino, Elaboración y aplicaciones constructivas de paneles prefabricados de escayola aligerada y reforzada con fibras de vidrio E y otros aditivos [Ph.D. Tesis], E.T.S. Arquitectura, Universidad Politécnica de Madrid, Madrid, Spain, 2009. 

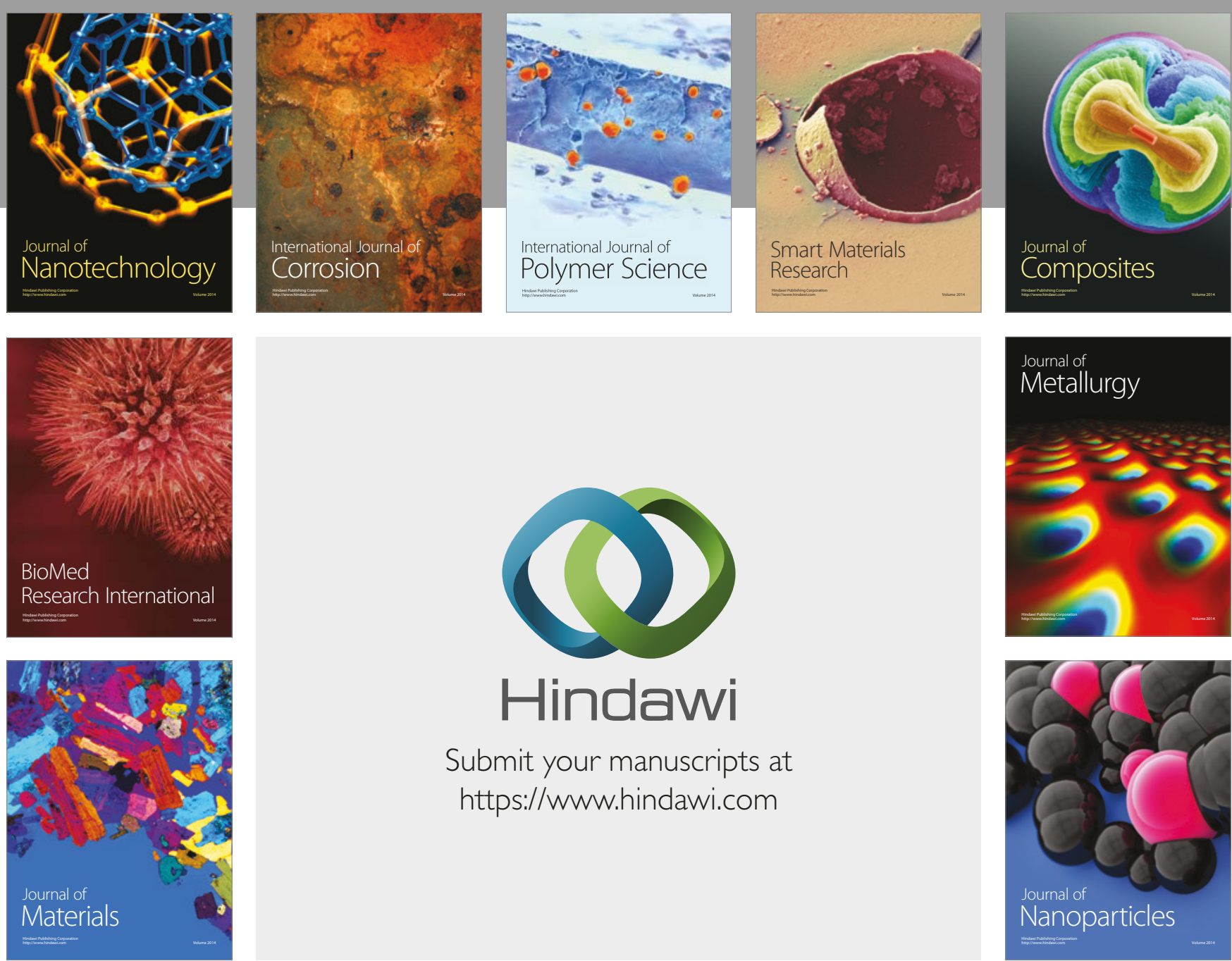

\section{Hindawi}

Submit your manuscripts at

https://www.hindawi.com
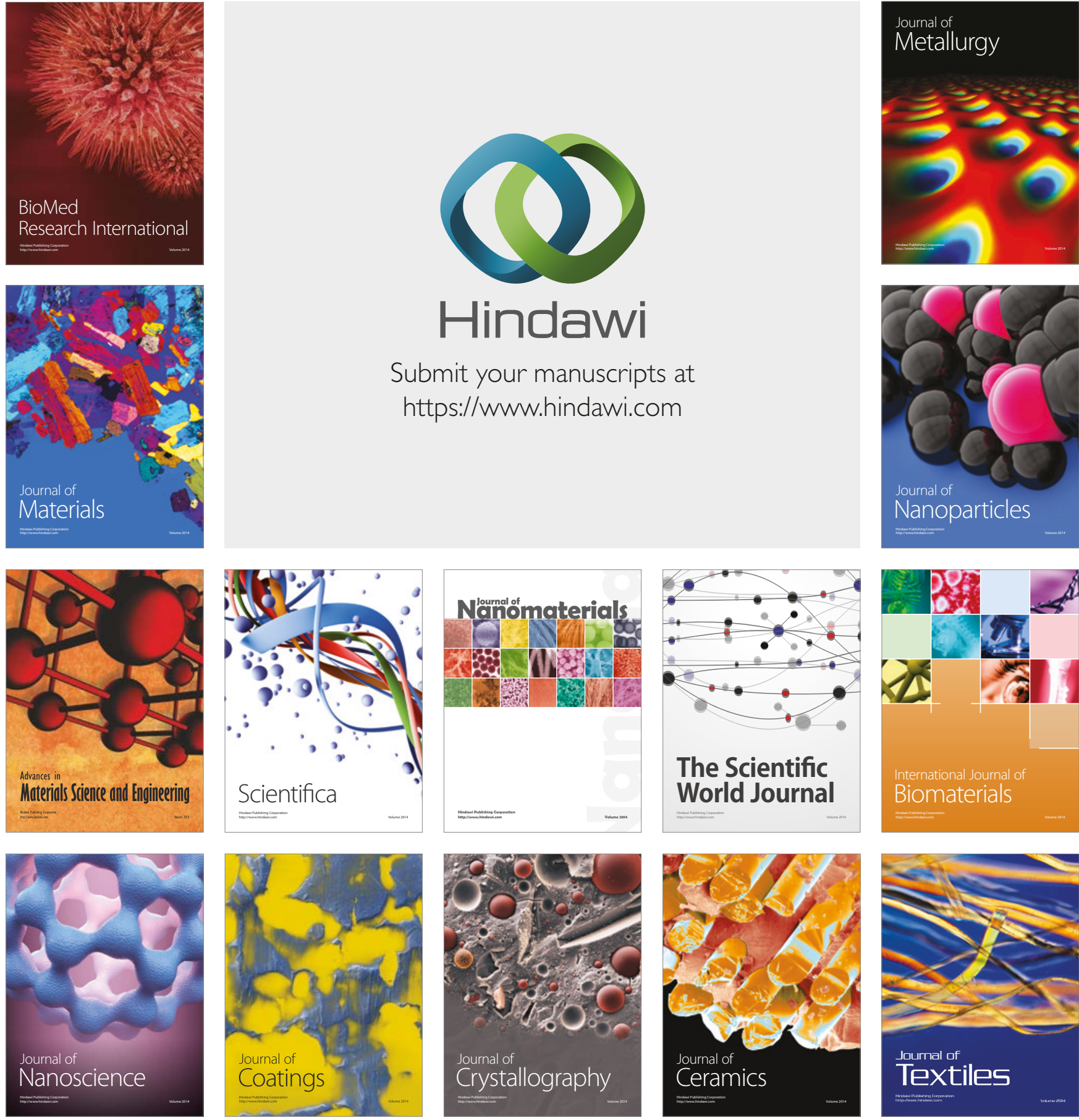

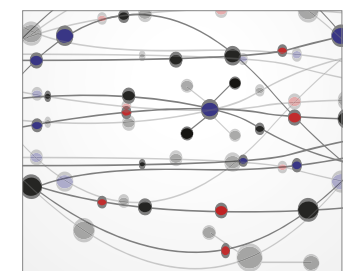

The Scientific World Journal
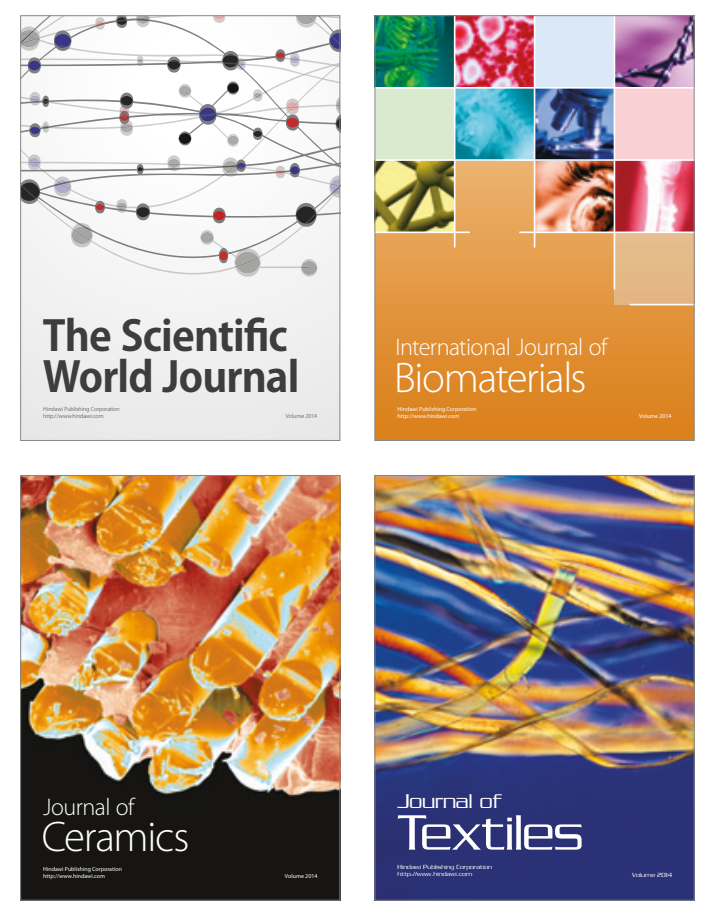